\title{
ENGINEERING JOURNAL
}

\section{CHIEF EDITOR}

Ahmad Faris Ismail, IIUM, Malaysia.

TECHNICAL EDITOR

Md. Noor Bin Salleh, IIUM, Malaysia.

EXECUTIVE EDITOR

Waqar Asrar, IIUM, Malaysia.

ASSOCIATE EDITOR

Anis Nurashikin Nordin, IIUM, Malaysia.

\section{LANGUAGE EDITOR}

Lynn Mason, IIUM, Malaysia.

\section{COPY EDITOR}

Hamzah Mohd. Salleh, IIUM, Malaysia.

\section{EDITORIAL BOARD MEMBERS}

A.K.M Nurul Amin, IIUM, Malaysia

Abdullah Al-Mamun, IIUM, Malaysia

Abdumalik Rakhimov, IIUM, Malaysia

Amir Akramin Shafie, IIUM, Malaysia

Erwin Sulaeman, IIUM, Malaysia

Hanafy Omar, Saudi Arabia

Hazleen Anuar, IIUM, Malaysia

Konstantin Khanin, University of Toronto, Canada

Luis Le Moyne, University of Burgundy, France

Ma'an Al-Khatib, IIUM, Malaysia

Md Zahangir Alam, IIUM, Malaysia

Meftah Hrairi, IIUM, Malaysia

Mohammed Konneh, IIUM, Malaysia

Mohammad S. Alam, University of South Alabama, United States

Mustafizur Rahman, National University Singapore, Singapore

Nurul Fadzlin Hasbullah, IIUM, Malaysia

Ossama Abdulkhalik, Michigan Technological University, United States

Rosminazuin AB. Rahim, IIUM, Malaysia

\section{AIMS \& SCOPE OF IIUM ENGINEERING JOURNAL}

The IIUM Engineering Journal, published biannually, is a carefully refereed international publication of International Islamic University Malaysia (IIUM). Contributions of high technical merit within the span of engineering disciplines; covering the main areas of engineering: Electrical and Computer Engineering; Mechanical and Manufacturing Engineering; Automation and Mechatronics Engineering; Material and Chemical Engineering; Environmental and Civil Engineering; Biotechnology and Bioengineering; Engineering Mathematics and Physics; and Computer Science and Information Technology are considered for publication in this journal. Contributions from other areas of Engineering and Applied Science are also welcomed. The IIUM Engineering Journal publishes contributions under Regular papers, Invited review papers, Short communications, Technical notes, and Letters to the editor (no page charge). Book reviews, reports of and/or call for papers of conferences, symposia and meetings, and advances in research equipment could also be published in IIUM Engineering Journal with minimum charges.

\section{REFEREES' NETWORK}

All papers submitted to IIUM Engineering Journal will be subjected to a rigorous reviewing process through a worldwide network of specialized and competent referees. Each accepted paper should have at least two positive referees' assessments.

\section{SUBMISSION OF A MANUSCRIPT}

A manuscript should be submitted online to the IIUM-Engineering Journal website:

journals.iium.edu.my/ejournal. Further correspondence on the status of the paper could be done through the journal website and the e-mail addresses of the Executive Editor: waqar@iium.edu.my Faculty of Engineering, International Islamic University Malaysia (IIUM), P.O. Box 10, 50728, Kuala Lumpur, Malaysia. Phone: (603) 6196 4482, Fax: (603) 61964853. 
ENGINEERING JOURNAL

INTERNATIONAL ADVISORY COMMITTEE

\begin{tabular}{|c|}
\hline Tibor Czigany \\
\hline Yiu-Wing Mai \\
\hline Luis Le Moyne, ISAT, University of Burgundy, France \\
\hline Razi Nalim, IUPUI, Indianapolis, Indiana, United States \\
\hline Farzad Ismail, USM, Pulau Pinang, Malaysia \\
\hline Ossama Abdulkhalik, Michigan Technological University, United States \\
\hline A. Anwar, United States \\
\hline Abdul Latif Bin Ahmad, Malaysia \\
\hline Hanafy Omar, Saudi Arabia \\
\hline Hany Ammar, United States \\
\hline Idris Mohammed Bugaje, Nigeria \\
\hline K.B. Ramachandran, India \\
\hline Kunzu Abdella, Canada \\
\hline M Mujtaba, United Kingdom \\
\hline Mohamed AI-Rubei, Ireland \\
\hline Mohamed B Trabia, United States \\
\hline M. Nazmul Karim, United States \\
\hline Syed Kamrul Islam, United States \\
\hline
\end{tabular}

Published by:

IIUM Journal Publication, International Islamic University Malaysia

P.O. Box 10, 50728 Kuala Lumpur, Malaysia

Tel: 03 - 6207 3507/3503/3502, Fax: (+603) 6196-6298

E-mail: journal_press@iium.edu.my

Website: http://journals.iium.edu.my

Printed by:

Perniagaan Normahs

No 3, 5 \& 7, Jalan 12/10,

Taman Koperasi Polis Fasa 1,

68100 Mukim Batu, Batu Caves,

Kuala Lumpur, Malaysia.

Whilst every effort is made by the publisher and editorial board to see that no inaccurate or misleading data, opinion or statement appears in this Journal, they wish to make it clear that the data and opinions appearing in the articles and advertisement herein are the responsibility of the contributor or advertiser concerned. Accordingly, the publisher and the editorial committee accept no liability whatsoever for the consequence of any such inaccurate or misleading data, opinion or statement. 